\title{
Perinatal hospice care in the opinion of nurses and midwives
}

\author{
Martyna Gruszka ${ }^{1,2}$, Grzegorz Kudela ${ }^{1}$, Agnieszka Wolny ${ }^{1}$, \\ Tomasz Koszutski ${ }^{1}$, Lidia Hyla-Klekot ${ }^{1}$ \\ ${ }^{1}$ Department of Pediatric Surgery and Urology, The Independent Public Clinical Hospital no. 6 of the Medical University of Silesia \\ in Katowice, Poland \\ ${ }^{2}$ Doctoral studies, School of Health Sciences of the Medical University of Silesia in Katowice, Poland
}

"Every child has four basic rights: the right to die, the right to the present day, the right to be what it wants to be, the right to express his thoughts and participate actively in our reflections and judgments considering himself".

J. Korczak

\begin{abstract}
Objectives: Perinatal medicine is a relatively new, dynamically developing branch of medicine. Its main purpose is taking care of a woman in the pre-conception period, pregnancy and delivery, as well as taking care of a newborn baby.

The main aim of the study was to assess the state of knowledge and opinion on hospice perinatal care of professionally active nurses and midwives.

Material and methods: An original and anonymous questionnaire containing 30 questions was used for the study. 572 nurses and midwives from the Silesian Voivodeship took part in the study. The obtained data were analyzed.

Results: Only $31.6 \%$ of respondents defined the level of their knowledge of pregnancy and neonatal care as high. $12.8 \%$ of respondents were able to indicate the definition of perinatal care and accurately determine its goals. The women participating in the study were in favor of enclosing the information about not attempting resuscitation (DNAR) in medical record of children with incurable disease diagnosed in fetal life (99.3\%).
\end{abstract}

Conclusions: The study showed deficits in practical and theoretical knowledge of nurses and midwives in the area of hospice perinatal care. Lack of proper preparation is also one of the most frequently mentioned difficulties in taking care of a child and family with poor prognosis.

Key words: nurses; midwives; perinatal care; perinatal hospice

Ginekologia Polska 2019; 90, 12: 702-706

\section{INTRODUCTION}

Perinatal care is a multidisciplinary procedure, covering the period of family planning, pre-conception, pregnancy, childbirth and puerperium, as well as a newborn baby care. Pregnancy is the period of prenatal diagnosis aimed at planning fetal and neonatal medical procedures in an institution with an appropriate referral level [1]. A multi-level model of perinatal care used worldwide can be divided into:

Level I units (well-newborn nurseries) which is a basic level of care during physiological pregnancy, delivery and puerperium. They have the capabilities to provide infants care at low risk and provide short-term care for unexpected pathology.
Level Il units (specialty) which provide care during moderate risk pregnancy, delivery and puerperium and care for infants who are moderately ill with problems that are expected to resolve rapidly.

Level III units (subspecialty) which provide care during high risk pregnancy, delivery and puerperium, as well as care for infants with the most severe pathologies [2].

Thanks to that division, many fetal defects can be quickly identified prenatally which enables performing fetal surgery or planning postnatal therapeutic strategy or terminating pregnancy in selected cases [3].

Despite that, still many serious developmental defects lead to spontaneous abortion, intrauterine or neonatal death 
or severe disability of the child [4]. Birth defects, next to prematurity, are the most common cause of neonatal deaths. Lethal defects are found in about $2-3 \%$ of neonatal deaths and in almost $10 \%$ of stillborn [4]. In Poland, however, detailed regulations concerning medical treatment of a child with lethal defects are missing. It is also worth noting that mother's decision of giving birth to a terminally ill baby is not equal to the decision of undertaking intensive therapy or complicated surgical procedures which can prolong the suffering and process of dying [5]. In case of not attempting aggressive treatment of the fetus or newborn one of the options is perinatal palliative (hospice) care, providing decent and adequate care not only to the newborn, but also to his parents [6].

\section{Aim of the study}

The aim of the study was to assess the state of knowledge and opinions about hospice perinatal care of professionally active nurses and midwives. An attempt was made to determine the degree of substantive and practical preparation of nurses and midwives to take care of a child with a lethal defect and his family.

\section{MATERIAL AND METHODS}

Five hundred seventy-two nurses and midwives working professionally in the Silesian Voivodeship were enrolled in the study. The study was conducted in the second quarter of 2017 , and the research group consisted only of women. The questionnaire was anonymous and voluntary, it comprised of 30 original questions. The questions were categorized into four thematic groups:

1. Issues concerning the characteristics of the test group;

\begin{tabular}{|c|c|c|}
\hline Characteristic & & $\mathrm{n}(\%)$ \\
\hline \multirow[t]{3}{*}{ Age } & $21-30(\%)$ & $259(45.3 \%)$ \\
\hline & $31-50(\%)$ & $281(49.1 \%)$ \\
\hline & $\geq 51(\%)$ & $32(5.6 \%)$ \\
\hline \multirow[t]{2}{*}{ Place of residence } & City (\%) & $485(84.8 \%)$ \\
\hline & Countryside (\%) & $87(15.2 \%)$ \\
\hline \multirow[t]{5}{*}{ Place of employment } & Pediatric Department (\%) & $365(63.8 \%)$ \\
\hline & $\begin{array}{l}\text { Gynecology \& Obstetrics } \\
\text { Department (\%) }\end{array}$ & $104(18.2 \%)$ \\
\hline & Primary Care (\%) & $11(1.9 \%)$ \\
\hline & Hospice (\%) & $53(9.3 \%)$ \\
\hline & Nursing home (\%) & $39(6.8 \%)$ \\
\hline \multirow[t]{5}{*}{ Education } & Higher (\%) & $195(34.1 \%)$ \\
\hline & Higher with specialty (\%) & $144(25.2 \%)$ \\
\hline & Secondary (\%) & $197(34.4 \%)$ \\
\hline & Secondary with specialty (\%) & $35(6.1 \%)$ \\
\hline & Vocational (\%) & $1(0.2 \%)$ \\
\hline
\end{tabular}

2. Questions checking the knowledge of the subjects about discussed topics;

3. Attitude towards the management of a child with a lethal defect including family care;

4. Preparation of nurses and midwives to work in perinatal hospice facilities.

The obtained data was analyzed.

\section{RESULTS}

\section{Characteristics of the studied group}

Five hundred seventy-two professionally active nurses and midwives were enrolled in the study. The group of respondents was $100 \%$ female. Table 1 presents the detailed characteristics of the study group.

\section{Knowledge of the respondents}

The respondents were asked to assess their knowledge about pregnancy and neonatal care in case of physiology and pathology - 200 women (35\%) defined their level of knowledge as satisfying, 109 (19\%) as low, and 181 (31.7\%) as high or very high. The most popular source of knowledge, for 201 respondents (35.1\%), were gynecologists and medical literature in the opinion of 112 women (21.5\%). Table 2 presents in detail the subjective assessment of the respondents' knowledge about obstetric, perinatal and hospice care.

\section{Opinion of the respondents}

The respondents were also asked about their opinion regarding hospice and futile medical care.

\begin{tabular}{l|l|l|}
\hline \multicolumn{3}{|l|}{$\begin{array}{l}\text { Table 2. Subjective assessment of the respondents' knowledge } \\
\text { and its sources }\end{array}$} \\
\hline Characteristic & n (\%) \\
\hline $\begin{array}{l}\text { Subjective assessment of the level of knowledge about pregnancy, } \\
\text { perinatal and hospice care }\end{array}$ & Very high (\%) & $1(0.2 \%)$ \\
\hline & High (\%) & $180(31.5 \%)$ \\
\hline & Satisfying (\%) & $200(35 \%)$ \\
\hline & Low (\%) & $109(19 \%)$ \\
\hline Source of knowledge & Not sufficient (\%) & $82(14.3 \%)$ \\
\hline & Medical literature (\%) & $121(21.5 \%)$ \\
\hline & Internet (\%) & $69(12.1 \%)$ \\
\hline & $\begin{array}{l}\text { School/university education } \\
\text { (\%) }\end{array}$ & $65(11.4 \%)$ \\
\hline & Family/friends (\%) & $31(5.4 \%)$ \\
\hline Gynecologist (\%) & $201(35.1 \%)$ \\
\hline Glossy magazines/guides (\%) & $17(3 \%)$ \\
\hline Work (\%) & $54(9.4 \%)$ \\
\hline Television (\%) & $14(2.4 \%)$ \\
\hline
\end{tabular}


In the opinion of 554 (96.8\%) women, futile medical care is synonymous with therapy that brings pain and suffering. Similarly, 568 (99.3\%) respondents are in favor of annotation about not attempting resuscitation (DNAR) and other medical procedures incapable of producing results in medical records of children with incurable disease diagnosed during pregnancy.

It is also significant that for 554 (96.8\%) respondents, women, who have decided not to treat a child with a lethal disorder, may encounter stigmatization and be classified as a "bad mother" by society. Table 3 presents the opinions of respondents about hospice care.

In the opinion of participants, in case of lethal defects, the most important tasks of medical personel include: providing professional psychological care -570 respondents

\begin{tabular}{|c|c|}
\hline Respondents' opinion & n (\%) \\
\hline $\begin{array}{l}\text { According to society, a woman who has made } \\
\text { a decision not to treat her child with a lethal disorder } \\
\text { is a "bad mother" }\end{array}$ & $554(96.8 \%)$ \\
\hline $\begin{array}{l}\text { Hospice care protects from suffering and futile } \\
\text { therapy }\end{array}$ & 511 (89.3\%) \\
\hline $\begin{array}{l}\text { Medical records should include an annotation about } \\
\text { non attempting resuscitation (DNAR) of children with } \\
\text { lethal disabilities }\end{array}$ & $568(99.3 \%)$ \\
\hline Futile therapy brings pain and suffering & $554(96.8 \%)$ \\
\hline $\begin{array}{l}\text { Every child should undergo all available medical } \\
\text { procedures despite an unfavorable diagnosis and } \\
\text { futile medical therapy }\end{array}$ & $18(3.1 \%)$ \\
\hline
\end{tabular}

Table 4. Most important tasks of medical personnel in perinatal hospice care in the opinion of the respondents

\begin{tabular}{|l|l|}
\hline The most important tasks of medical personnel & $\mathbf{n}(\%)$ \\
\hline Providing professional psychological care & $570(99.6 \%)$ \\
\hline $\begin{array}{l}\text { Explanation of the child's disease, its prognosis and } \\
\text { possible scenarios of treatment }\end{array}$ & $459(80.2 \%)$ \\
\hline $\begin{array}{l}\text { Specialized medical care from prenatal diagnosis till } \\
\text { childbirth }\end{array}$ & $508(88.8 \%)$ \\
\hline \begin{tabular}{l} 
Discussing the rules of hospice care \\
\hline $\begin{array}{l}\text { Providing conditions for treatment and rehabilitation } \\
\text { of a child with incurable disease }\end{array}$
\end{tabular} & $318(55.6 \%)$ \\
\hline $\begin{array}{l}\text { Help in preparing the house and medical equipment } \\
\text { necessary to care for a newborn with incurable } \\
\text { disorders }\end{array}$ & $189(33 \%)$ \\
\hline $\begin{array}{l}\text { Providing social and spiritual help } \\
\text { Ensuring the presence of loved ones }\end{array}$ & $232(40.6 \%)$ \\
\hline $\begin{array}{l}\text { Enabling contact with other parents of a child } \\
\text { suffering from lethal disorder }\end{array}$ & $467(81.6 \%)$ \\
\hline $\begin{array}{l}\text { Caring for pregnant woman and preparing for } \\
\text { delivery of a newborn affected by e.g. severe CNS } \\
\text { defect }\end{array}$ & $248(43.3 \%)$ \\
\hline $\begin{array}{l}\text { Providing comprehensive care for couples whose } \\
\text { child died during pregnancy }\end{array}$ & $515(90 \%)$ \\
\hline
\end{tabular}

(99.6\%) and preparation of parents for delivery - 515 respondents (90\%). 459 (80.2\%) participants consider proper explanation of the disease, its prognosis and possible scenarios of medical treatment as equally important. Table 4 presents the most important tasks of medical staff in hospice perinatal care.

The respondents also indicated a number of obstacles in child and parent care at the time of unfavourable perinatal diagnosis. The most troublesome for nurses and midwives is the lack of medical knowledge (307 respondents, 53.7\%) and the lack of clear medical procedures in health care facilities (456 respondents, 79.7\%). 216 (37.8\%) nurses and midwives also indicated the lack of an adequate psychological preparation to understand the problems, feelings and emotions of the dying child's family as the next most difficult aspect in hospice perinatal care. Table 5 presents the problems in perinatal hospice care in the opinion of surveyed women.

\section{Substantive and practical preparation}

Unfortunately, only 265 (46.3\%) nurses and midwives were able to indicate where the perinatal hospice is functioning in Poland, and 205 (35.9\%) clearly suggest that there is no such a facility in our country.

Only $18(3.1 \%)$ respondents declared that in the academic classes they became familiar with the term hospice perinatal care, while 307 (53.7\%) respondents did not discussed this issue at all. However, 274 (47.9\%) respondents declare the lack of practical preparation to care for a woman who knows that her child will be born terminally ill. For 530 (92.6\%) respondents working with family of terminally ill newborn would be difficult and they would prefer not to take part in it. The most often indicated reasons for

Table 5. Difficulties in hospice perinatal care in the opinion of nurses and midwives

\begin{tabular}{|l|l|}
\hline Difficulties in hospice perinatal care & $\mathbf{n}(\%)$ \\
\hline Lack of clear medical procedures & $456(79.7 \%)$ \\
\hline Lack of medical knowledge & $307(53.7 \%)$ \\
\hline Lack of proper practical preparation & $185(32.3 \%)$ \\
\hline Fear of legal consequences & $279(48.8 \%)$ \\
\hline Lack of psychological preparation & $216(37.8 \%)$ \\
\hline Fear of the death of a child & $178(31.1 \%)$ \\
\hline $\begin{array}{l}\text { Personal attitude to the issue of futile therapy or } \\
\text { resuscitation of children with a lethal defect }\end{array}$ & $131(22.9 \%)$ \\
\hline $\begin{array}{l}\text { Limited access to material and non-material } \\
\text { resources in hospice care }\end{array}$ & $149(26 \%)$ \\
\hline
\end{tabular}


Table 6. Assessment of substantive and practical preparation of the respondents

\begin{tabular}{|l|l|}
\hline Substantive and practical preparation & $\mathbf{n}(\%)$ \\
\hline $\begin{array}{l}\text { Lack of knowledge about the perinatal hospice } \\
\text { activity in Poland }\end{array}$ & $205(35.9 \%)$ \\
\hline $\begin{array}{l}\text { Willingness to take care of the family and a newborn } \\
\text { who requires hospice perinatal care }\end{array}$ & $42(7.3 \%)$ \\
\hline $\begin{array}{l}\text { Deficit of knowledge about perinatal hospice care of } \\
\text { a newborn and his family }\end{array}$ & $307(53.7 \%)$ \\
\hline $\begin{array}{l}\text { Deficit of empathy in caring for a newborn and } \\
\text { a family requiring perinatal hospice care }\end{array}$ & $135(23.6 \%)$ \\
\hline $\begin{array}{l}\text { Lack of practical preparation for care of a newborn } \\
\text { baby and a family requiring perinatal hospice care }\end{array}$ & $274(47.9 \%)$ \\
\hline
\end{tabular}

such attitude were: lack of knowledge about taking care of terminally ill newborn (307 respondents, 53.7\%) and fear of having low level of empathy (135 respondents, $23.6 \%$ ). Table 6 presents the assessment of the level of preparation for perinatal hospice care.

\section{DISCUSSION}

At present, there are over 250 organizations worldwide dealing with perinatal hospice care, including Polish examples: Silesian Perinatal Hospice, Warsaw Perinatal Hospice, or JózefTischner Hospice for Children in Cracow [1]. Therefore, it should be appreciated that Poland is one of the European countries with a very well-developed hospice network. However, despite the dynamic development of hospice care for children, the problem of recruiting well-qualified personnel and the proper education of new adepts in this field remains relevant. In spite of the fact that palliative care has been part of the curriculum for nursing and midwifery students in Poland for the last few years, the vast majority of it covers aspects of adult patients care [7]. Similarly in postgraduate education, although midwives can specialize in 4 basic disciplines and nurses in 15, still not enough attention is paid to the problem of perinatal hospice care in specialist training programs [8].

As shown in the study by Dangel T. et al. perinatal palliative care alone is not well-spread and seems to be overlooked by medical personnel [1]. The same conclusion can be drawn from our research. Nurses and midwives as a professional group are often the first to confront mothers and children suffering from lethal inborn defects. However, they show significant deficiencies in the knowledge of perinatal hospice care issues. Although respondents are able to point out a spectrum of defects and diseases that can classify a newborn to a perinatal hospice, and mostly determine their level of knowledge as high or satisfying, they feel the need to broaden their knowledge in this area. They emphasize deficiencies in substantive and practical preparation as the greatest difficulties in caring for a child and a parent dealing with lethal defect. Similarly, in the study of Korzeniewska-Eksterowicz A. et al., over $80 \%$ of surveyed neonatologists and nurses indicate insufficient knowledge of medical personnel as the biggest barrier in palliative care [7]

Only $7.3 \%$ of surveyed nurses and midwifes would take care of the family and the newborn in the perinatal hospice. At the same time, the respondents indicate that the most important task of medical staff is providing specialist psychological care. As in the study of Jaraczak A. et al. [9], the respondents pointed to the important role of psychological support for women with high-risk pregnancy. This study, conducted on 136 pregnant women, showed that support of midwives in the process of childbirth is very important. However, $37.8 \%$ of respondents declare lack of readiness to understand the problems, feelings and emotions of the dying child's family which is the next most difficult aspect in hospice perinatal care.

It seems reasonable to increase the scope of knowledge about the perinatal hospice and the practical and psychological preparation of nurses and midwives to work in such places during the education and specialization courses.

\section{CONCLUSIONS}

1. The respondents assess their state of knowledge as not sufficient to take care of a pregnant woman and her child with prenatally diagnosed lethal defect and a newborn baby at the time of death.

2. Nurses and midwives are reluctant to take care of a child and family with an unfavourable diagnosis already made in the perinatal period. The biggest barrier in providing such care is feeling of deficiencies in substantive, practical and psychological preparation.

3. In the opinion of nurses and midwives the most important task of medical staff in caring for a pregnant woman with diagnosed lethal disability in her child is to provide proper psychological care.

\section{REFERENCES}

1. Dangel T, Szymkiewicz-Dangel J. Opieka paliatywna w perinatologii. Opieka paliatywna nad dziećmi. Wydanie XIII., Warszawa 2005.

2. Pietrzycka D, Gadzinowski J. Opieka perinatalna w krajach Europy Środkowej i Wschodniej. Klin Perinatol Ginekol. 2007; 43(3): 3-7.

3. Koszutski T, Kawalski H, Kudela $G$, et al. Babies with myelomeningocele in Poland: parents' attitudes on fetal surgery versus termination of pregnancy. Childs Nerv Syst. 2009; 25(2): 207-210, doi: 10.1007/s00381008-0653-1, indexed in Pubmed: 18560842.

4. Szmyd K, Śmigiel R, Królak-Olejnik B. Propozycje postępowania z noworodkiem w przypadku rozpoznania wady letalnej w okresie prenatalnym. Pediatria Polska. 2014; 89(6): 389-394, doi: 10.1016/j. pepo.2014.08.004.

5. Frączek P, Jabłońska M, Pawlikowski J. Medyczne, etyczne, prawne i społeczne aspekty badań prenatalnych w Polsce. Med Ogólna Nauki Zdr. 2013; 9(2): 103-109.

6. Marty $C M$, Carter BS. Ethics and palliative care in the perinatal world. Semin Fetal Neonatal Med. 2018; 23(1): 35-38, doi: 10.1016/j. siny.2017.09.001, indexed in Pubmed: 28916237

7. Korzeniewska-Eksterowicz A, Respondek-Liberska M, Przysło $\measuredangle$, et al. Perinatal palliative care: barriers and attitudes of neonatologists and 
nurses in Poland. ScientificWorldJournal. 2013; 2013: 168060, doi: 10.1155/2013/168060, indexed in Pubmed: 24288459.

8. Rozporządzenie Ministra Zdrowia z dnia 12 grudnia 2013r. w sprawie wykazu dziedzin pielęgniarstwa oraz dziedzin mających zastosowanie w ochronie zdrowia, w których może być prowadzona specjalizacja i kursy kwalifikacyjne (Dz. U. poz. 1562).
9. Jaraczak A, Kosoń K. Jakość opieki perinatalnej w Polsce w ocenie kobiet rodzących w latach 1990-2013. Perinatol Neonatol Ginekol. 2013; 6(3): 161-167. 